\title{
綿布の過酸化水素漂白における尿素の添加効果
}

\author{
奈良女子大学大学院 人間文化研究科 梁 善美 \\ 大阪府立産業技術総合研究所 田原 充 \\ 奈良女子大学生活環境学部 前川昌子
}

\section{Effects of Urea on Hydrogen Peroxide Bleaching of Cotton Fabrics}

\author{
Sunmi Yang ${ }^{* 1}$, Mitsuru Tahara ${ }^{* 2}$, and Masako Maekawa ${ }^{* 3}$ \\ ${ }^{* 1}$ Graduate School of Human Culture, Nara Women's University, Nara 630-8506, Japan \\ *2 Technology Research Institute of Osaka Prefecture, 7-1, Ayumino 2, Izumi, Osaka 594-1157, Japan \\ ${ }^{* 3}$ Faculty of Human Life and Environment, Nara Women's University, Nara 630-8506, Japan
}

\begin{abstract}
In order to establish the bleaching process for cotton fabrics under the neutral condition, cotton fabrics were bleached by hydrogen peroxide with urea. It was revealed that hydrogen peroxide bleaching with urea showed the higher whiteness of bleached fabrics than that without urea at more than $70^{\circ} \mathrm{C}$. Tensile strength did not decrease after bleaching. Some radicals were observed by ESR measurement when urea was added into hydrogen peroxide aqueous solution. The effects of urea on hydrogen peroxide bleaching seems to be caused by active oxygen; hydroxyl radical (HO), perhydroxyl radical (HOO) and superoxide anion radical $\left(\mathrm{O}_{2^{-}}{ }^{-}\right)$as well as perhydroxyl anion $\left(\mathrm{HOO}^{-}\right)$. The residual hydrogen peroxide concentrations in bleaching baths were measured. When urea is added to the bleaching baths, the decomposition of hydrogen peroxide is accelerated even in the neutral bath.
\end{abstract}

(Received 3 September, 2009 ; Accepted 6 October, 2009)

\section{1. 緒 言}

近年, 環境負荷の小さい瀻維加工が求められており， 漂白工程に抢いても従来の塩素系漂白郕から AOX (Absorbable Organic Halogen)を生成しない酸素系漂白郕へ の移行が進んでいる．過酸化水素水溶液は弱酸として働 き, 水と同程度の解離定数を示す安定な物質であるため, 過酸化水素の解離を促進し, 活性化する必要がある [1]. ここ数年, 省エネルギーの観点から, 常温, 中性条件で 過酸化水素を活性化して漂白効果を得る様々な研究が行 われている。例えば，バイオテクノロジーを用いる酵素 による漂白 $[2,3]$, 有機過酸として使用する方法 $[4]$, 無機

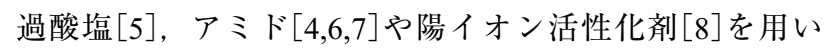
る方法などがある。 さらに近年は，レーザー光を用いて 着色物質の電子を励起させ, 酸化ないしは還元漂白が容 易に進むようにする方法も報告されている 99$]$. 特にアミ ドを用いる研究では，T. K. Das らが綿布の漂白において 尿素を含む数種のアミドを漂白時間を短縮する目的で使 用して抢り, 尿素が白度, 強度, コストの面で優れてい ると報告している[7]. 先染め品やアルカリに敏感な素材 との混紡品の漂白として, 中性㧍よび弱酸性での過酸化 水素漂白が既に行われているが, これには過酸化水素活 性化剂として尿素とリン酸塩を含む Prestogen SP(BASF)
が用いられている[4]。一方, 包接化合物を生成する尿素 の性質を利用し, 尿素の過酸化水素水溶液を再結晶化し た UHP(尿素-過酸化水素付加体)は安価で使いやすい環境 親和的な酸化剂として知られており, 洗浄剤、漂白剤、 染毛剂などの用途で期待されている $[10,11,12]$.

本研究では尿素の過酸化水素活性化作用に着目し, 中 性条件での漂白を目的として, 綿布を用いて尿素を助剤 とした過酸化水素漂白を行い, 漂白綿布の白度 $(\mathrm{WI})$ 拈よ び強伸度を測定した。また, 電子スピン共鳴装置 (ESR)を 用いて尿素添加によるラジカル生成について検討した。 さらに酸化還元滴定により漂白浴に残留する過酸化水素 の濃度を測定し, 尿素添加と過酸化水素解離との関係を 調べた.

\section{2. 実 験}

\section{1 試料}

過酸化水素 (35\%, キシダ化学社製), 尿素(Ultra Pure, $\mathrm{CH}_{4} \mathrm{~N}_{2} \mathrm{O}$, ICN Biomedical, Inc 製), 浸透剂として非イオ ン界面活性剂(スコアロール，花王社製）を用いて漂白液 を作成した。綿布はクラボウ(侏提供の酵素精練した平織 布を使用した。

さらにラジカル補足剂として DMPO(東京化成工業侏社 
製，5,5-Dimethyl-1-pyrroline N-oxide）を用いた。

\section{2 過酸化水素-尿素漂白}

過酸化水素漂白における尿素添加効果を調べるために 綿布を用いて過酸化水素を $0.23 \mathrm{~mol} / \mathrm{dm}^{3}$, 尿素を 0.08 $2 \mathrm{~mol} / \mathrm{dm}^{3}$, 浸透剂としてスコアロールを $0.5 \mathrm{ml} / \mathrm{dm}^{3}$ で漂白 液を調製し, 温度 $30 \sim 80^{\circ} \mathrm{C}$ で 5 120 分, 浴比 $1: 60$ で漂 白した。

\section{3 白度測定}

漂白布の白度は分光式色差計 (日本電色 SE-2000) 用 いて測定した. $\mathrm{C}$ 光源, 2 度視野で, 試料を 4 つ折りにし 3 箇所測定して平均し, ASTM E 313 白色度式により白度 (WI) を求めた.

$\mathrm{WI}=3.388 \mathrm{Z}-3 \mathrm{Y}$

$Z$ : 試料の XYZ 表色系における三刺激值 $\mathrm{Z}$ の值

$\mathrm{Y}$ : 試料の XYZ 表色系における三刺激值 $\mathrm{Y}$ の值

\section{4 漂白浴の $\mathrm{pH}$ 測定}

$\mathrm{pH}$ 測定は HORIBA F-8 の pH メーターで行った. 漂白 溶は $\mathrm{pH}$ 無調製の精製水に過酸化水素 $0.23 \mathrm{~mol} / \mathrm{dm}^{3}$ と 0.08〜 $1.5 \mathrm{~mol} / \mathrm{dm}^{3}$ までの各尿素濃度を加えて用いた. 比 較として過酸化水素単独や尿素単独の漂白浴の $\mathrm{pH}$ も測定 した。 そして調整した溶液の入った三角プラスコを恒温 槽に入れて、 $70^{\circ} \mathrm{C}$ に維持しながら、10〜 120 分測定した.

\section{5 電子スピン共鳴装置 (ESR) によるフリーラジカ} ルの測定

日本電子製フリーラジカルモニタ FR-30を用いてフ リーラジカルの測定を常温で行った. 測定条件はマイク 口波出力 $4 \mathrm{~mW}$, 磁場掃引幅 $5.000 \mathrm{mT}$, 磁場掃引時間 $1.0 \mathrm{~min}$ として 3 回積算した. シグナル強度の評価は内部標準物 質である $\mathrm{Mn}^{2+}$ のシグナルピークに対して行った.

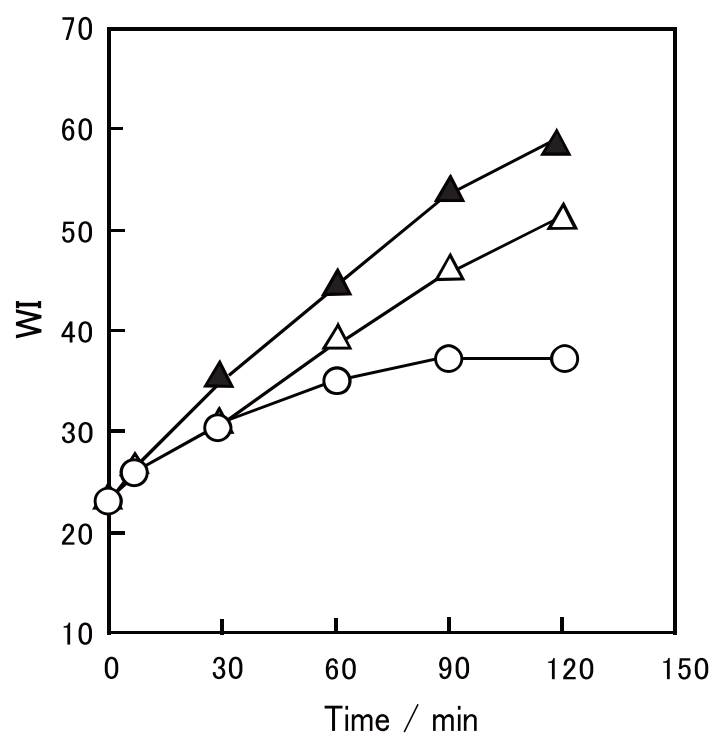

Fig. 1 Change of WI by addition of urea with different concentrations in hydrogen peroxide bleaching of cotton fabrics $\left(\mathrm{H}_{2} \mathrm{O}_{2} 0.23 \mathrm{~mol} / \mathrm{dm}^{3}, 70^{\circ} \mathrm{C}\right)$. $\bigcirc$ : None, $\triangle$ : Urea $0.5 \mathrm{~mol} / \mathrm{dm}^{3}, \boldsymbol{\Delta}$ : Urea $1 \mathrm{~mol} / \mathrm{dm}^{3}$

\section{6 過酸化水素濃度の測定}

日本工業規格 (JIS K-8230)に規定されている方法(過マ ンガン酸カリウム滴定法)により過酸化水素濃度を測定し た. 試料として $35 \%$ 過酸化水素を $2 \mathrm{ml}$, 尿素 $0.6 \mathrm{~g}$, 精製 水, $\mathrm{NaOH}(\mathrm{pH} 6,10$ に調製) で全体を $20 \mathrm{ml}$ に調製して用 いた. $80^{\circ} \mathrm{C}$ に設定した恒温槽に試料を入れた三角フラス コを入れて $10 ， 30 ， 60 ， 90 ， 120$ 分に試料を採取し, $0.02 \mathrm{~mol} / \mathrm{dm}^{3}$ の過マンガン酸カリウム溶液で滴定を行い, 過酸化水素濃度を求めた.

\section{7 強伸度の測定}

多目的引張り測定機 KES-G1 (カトーテック(株社製)を 用いて強伸度の測定を行った。試料長 $10 \mathrm{~cm}$, 強伸速度 $10 \mathrm{~cm} / \mathrm{min}$ で漂白布から得た縦系 10 本を測定に供し, 平均 值を強度とした。

\section{3. 結果と考察}

過酸化水素は弱い酸で, 水溶液中で水素 $\left(\mathrm{H}^{+}\right)$とペルヒ ドロキシルイオン $\left(\mathrm{HOO}^{-}\right)$に解離する. しかし, その解離 指数は $11.6\left(25^{\circ} \mathrm{C}\right)$ や $10.71\left(80^{\circ} \mathrm{C}\right)$ で, 過酸化水素単独では 水溶液中でほとんど酸化作用を示さない，過酸化水素は アルカリ条件下で,（1）式のように過酸化水素の解離が進 み, 有力な漂白種であるペルヒドロキシルイオン $\left(\mathrm{HO}_{2}^{-}\right)$ の濃度が高くなる.しかし, 生成したペルヒドロキシル イオンは不安定なため, さらに解離して, (2)式のように 酸素 $\left(\mathrm{O}_{2}\right)$ とアルカリ $\left(\mathrm{OH}^{-}\right)$に自己分解が進んでいく $[1,13]$.

$$
\begin{aligned}
& \mathrm{H}_{2} \mathrm{O}_{2}+\mathrm{OH}^{-} \rightleftarrows \mathrm{H}_{2} \mathrm{O}+\mathrm{HOO}^{-} \\
& 2 \mathrm{HOO}^{-} \rightleftarrows 2 \mathrm{OH}^{-}+\mathrm{O}_{2}
\end{aligned}
$$

またペルヒドロキシルイオンと同様, 漂白作用を有す ると考えられるペルヒドロキシルラジカル (HOO.)やスー パーオキシドアニオンラジカル $\left(\cdot \mathrm{O}_{2}^{-}\right)$の濃度も $\mathrm{pH} 8.5-11.6$

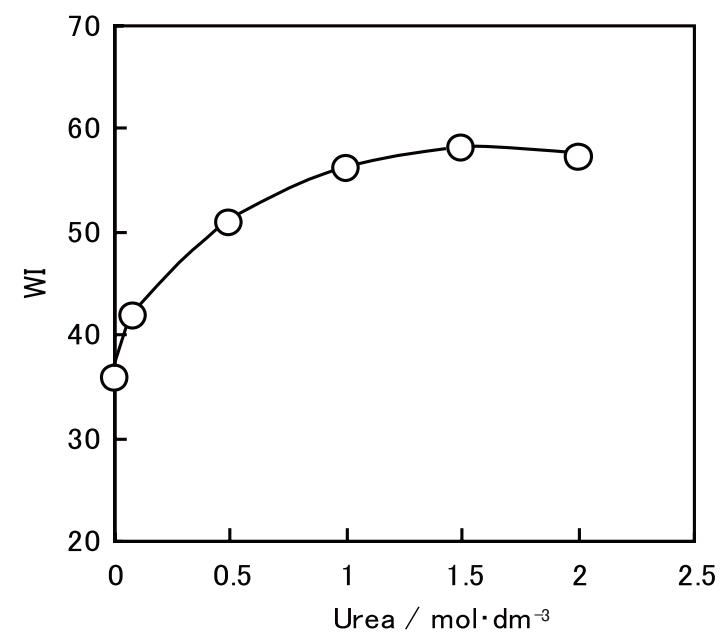

Fig. 2 Relation between concentrations of urea and WI in hydrogen peroxide bleaching of cotton fabrics $\left(\mathrm{H}_{2} \mathrm{O}_{2} 0.23 \mathrm{~mol} / \mathrm{dm}^{3}, 70^{\circ} \mathrm{C}, 120 \mathrm{~min}\right)$. 
の範囲において高くなる(式 3-4) [14].

$$
\begin{aligned}
& \mathrm{H}_{2} \mathrm{O}_{2}+2 \mathrm{OH} \rightleftarrows \cdot \mathrm{O}_{2}^{-}+2 \mathrm{H}_{2} \mathrm{O}+\mathrm{e}^{-} \\
& \mathrm{HOO} \rightarrow \mathrm{O}_{2}^{-}+\mathrm{H}^{+}
\end{aligned}
$$

Fig. 1 は過酸化水素を用い, 尿素を添加して 5 120 分 間漂白を行った綿布の WI を示す。過酸化水素単独で漂白 した綿布の WI に比べ, 尿素を添加して漂白した綿布の方 が明らかに WI が高い. また尿素濃度と WI との関係では, Urea $0.5 \mathrm{~mol} / \mathrm{dm}^{3}$ で漂白した場合より, その 2 倍の濃度で 漂白した方がより高いWI を示した.

Fig. 2 に尿素濃度と漂白綿布の WI の関係を示す．尿素 濃度が $1.5 \mathrm{~mol} / \mathrm{dm}^{3}$ までは尿素濃度が高くなるにつれて WI は明らかに上昇したが，それ以上の濃度では WI は高くな らなかった。

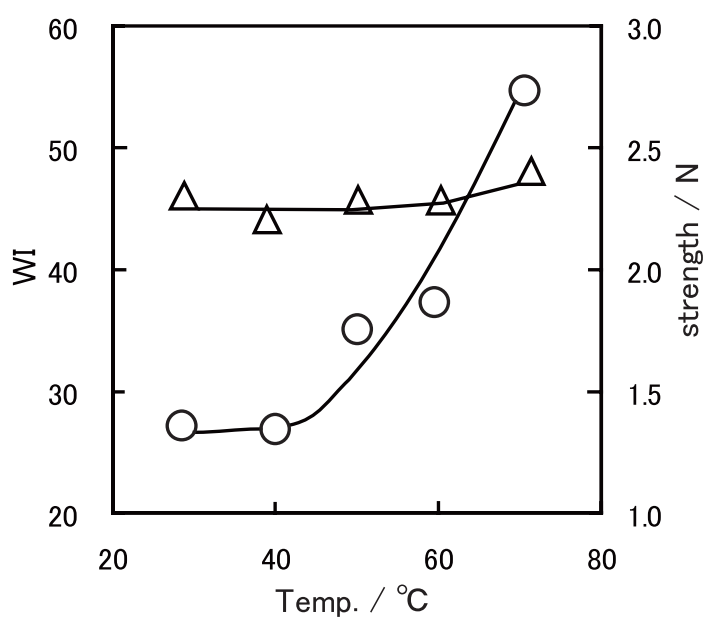

Fig. 3 Effects of bleaching temperature on WI or tensile strength of cotton fabrics in hydrogen peroxide bleaching with urea $\left(\mathrm{H}_{2} \mathrm{O}_{2} 0.23 \mathrm{~mol} / \mathrm{dm}^{3}\right.$, Urea $\left.1 \mathrm{~mol} / \mathrm{dm}^{3}, 120 \mathrm{~min}\right) . \bigcirc$ : WI, $\triangle$ : strength

Fig. 3 に漂白綿布の WI と引張強度に対する漂白浴の温 度の影響を示す．温度は $30^{\circ} \mathrm{C}$ から $70^{\circ} \mathrm{C}$ まで変化させた。

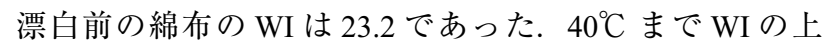
昇はほとんど見られないが, それ以上では温度の上昇と ともに WI は上昇し $70^{\circ} \mathrm{C}$ で大幅に上がったＷI を高くす る漂白温度, 過酸化水素濃度, 尿素濃度などの諸要因の 中で, 最もその影響が大きいのは温度であった。一方, 引張り強度は温度の変化にほとんど依存せず, 漂白前と 比較しても低下は見られなかった. 重金属のような触媒 作用をするものが存在すると, 電気的に中性である $\mathrm{OH}$. を生成するため, セルロースに作用しやすく, 強度低下 や損傷を起こす.アルカリ条件下で生成される過酸化水 素の漂白種は式(1)〜 (4)のようにペルヒドロキシルイオ ン $\left(\mathrm{HOO}^{-}\right)$やペルヒドロキシルラジカル $(\mathrm{HOO} \cdot)$, スーパー オキシドアニオンラジカル $\left(\cdot \mathrm{O}_{2}^{-}\right)$で, 中でも $\mathrm{HOO}^{-}$や $\mathrm{O}_{2}^{-}$ はアルカリ浴中で負に帯電しているセルロースとは反発 しあい, 繊維に損傷を与える恐れがない[15].
過酸化水素の漂白種は $\mathrm{pH}$ と大きく関わりがあるゆえ, 漂白浴の $\mathrm{pH}$ 変化について調べてその結果を Fig. 4 に示す. 過酸化水素単独では $25^{\circ} \mathrm{C}$ で pH5.8 を示すが, 漂白浴の温 度が $70^{\circ} \mathrm{C}$ で時間が経過しても, pHの変化はほとんどな い. 一方, 尿素単独では温度上昇後, 時間とともに $\mathrm{pH} も$ 上昇する. これは, 高温で尿素が加水分解して生成され るアンモニアによるものだと考えられる[3]. アンモニア の発生は漂白後のアンモニア臭からも確認できた.

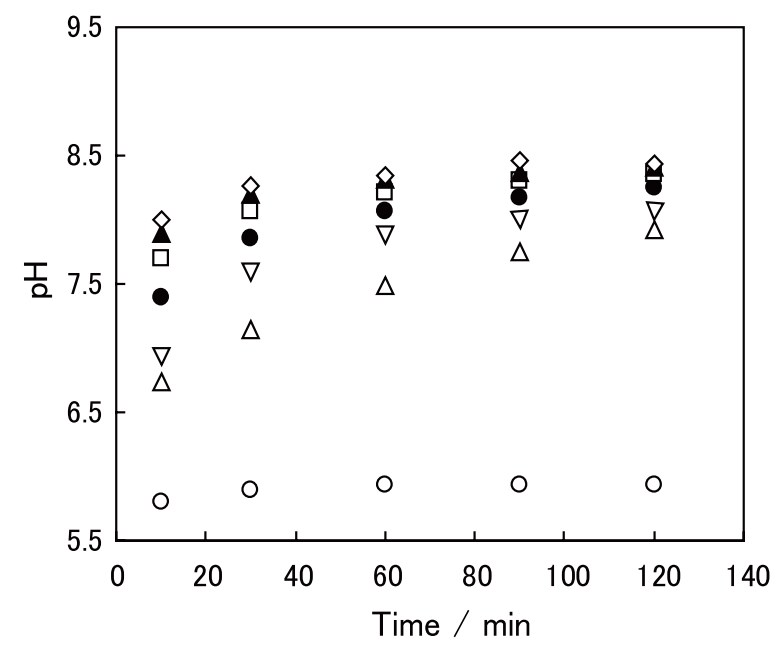

Fig. 4 Change of $\mathrm{pH}$ for hydrogen peroxide / Urea bleaching baths $\left(70^{\circ} \mathrm{C}\right)$.

$\bigcirc: \mathrm{H}_{2} \mathrm{O}_{2} 0.23 \mathrm{~mol} / \mathrm{dm}^{3}, \triangle$ : Urea $1 \mathrm{~mol} / \mathrm{dm}^{3}$ $\nabla: \mathrm{H}_{2} \mathrm{O}_{2} 0.23 \mathrm{~mol} / \mathrm{dm}^{3}+$ Urea $0.08 \mathrm{~mol} / \mathrm{dm}^{3}$

: $\mathrm{H}_{2} \mathrm{O}_{2} 0.23 \mathrm{~mol} / \mathrm{dm}^{3}+$ Urea $0.23 \mathrm{~mol} / \mathrm{dm}^{3}$

$\square: \mathrm{H}_{2} \mathrm{O}_{2} 0.23 \mathrm{~mol} / \mathrm{dm}^{3}+$ Urea $0.5 \mathrm{~mol} / \mathrm{dm}^{3}$

A : $\mathrm{H}_{2} \mathrm{O}_{2} 0.23 \mathrm{~mol} / \mathrm{dm}^{3}+$ Urea $1 \mathrm{~mol} / \mathrm{dm}^{3}$

$\diamond: \mathrm{H}_{2} \mathrm{O}_{2} 0.23 \mathrm{~mol} / \mathrm{dm}^{3}+$ Urea $1.5 \mathrm{~mol} / \mathrm{dm}^{3}$

続いて, 過酸化水素に尿素を添加すると, $\mathrm{pH}$ はただち に上昇し，10 分から 60 分後にはほぼ一定となる. また尿 素単独より $\mathrm{pH}$ はさらに上昇する. 尿素の濃度が高くなる につれて $\mathrm{pH}$ も高くなるが, 尿素濃度 $1.5 \mathrm{~mol} / \mathrm{dm}^{3}$ 以上に なると pH はそれ以上は上昇しない.この結果は Fig. 2 で， 尿素濃度 $1.5 \mathrm{~mol} / \mathrm{dm}^{3}$ まで WI が上昇することと符合する。 一方, 尿素を添加した過酸化水素漂白浴の漂白布の WI は 処理浴の $\mathrm{pH}$ に関係なくほほ一定值を示すことが報告され ている [3]. 漂白浴の漂白後の $\mathrm{pH}$ の変化に関しては, 過 酸化水素単独で $\mathrm{pH} 6,7,8$ の場合, 漂白後の $\mathrm{pH}$ が幾分 下がるが, $\mathrm{pH} 9$ で漂白後の $\mathrm{pH}$ が約 9.4 になる. 一方, 尿 素を添加した漂白浴では $\mathrm{pH} 6$ から $\mathrm{pH}$ までの $\mathrm{pH}$ がいず れも 9.5 の前後となった. アンモニアによる $\mathrm{pH}$ の上昇が WI に及ぼす影響を知るために，尿素を用いず，アンモニ アもしくは水酸化ナトリウムを用いて, 尿素を入れたと きの漂白後の $\mathrm{pH}$ 值に調製し, 漂白を行った結果を Fig. 5 に示す.アンモニアもしくは水酸化ナトリウムで調製し た綿布の WI は, ほぼ同じ程度で, 尿素で調製した漂白綿 布に比べ，明らかに低いWI を示した．これはアンモニア の生成による $\mathrm{pH}$ の上昇だけではない, 尿素としての他の 
効果があることを示唆する. 尿素を添加した過酸化水素 水溶液の酸化還元電位 $(\mathrm{ORP})$ を測定した結果, 過酸化水 素漂白浴に尿素を添加すると酸性, 中性, アルカリ性に かかわらず ORP はやや下がる傾向が見られたが，その低 下はおよそ $20 \mathrm{mV} \sim 40 \mathrm{mV}$ 程度のもので, $\mathrm{pH}$ による変化 と比べて小さなものであった.

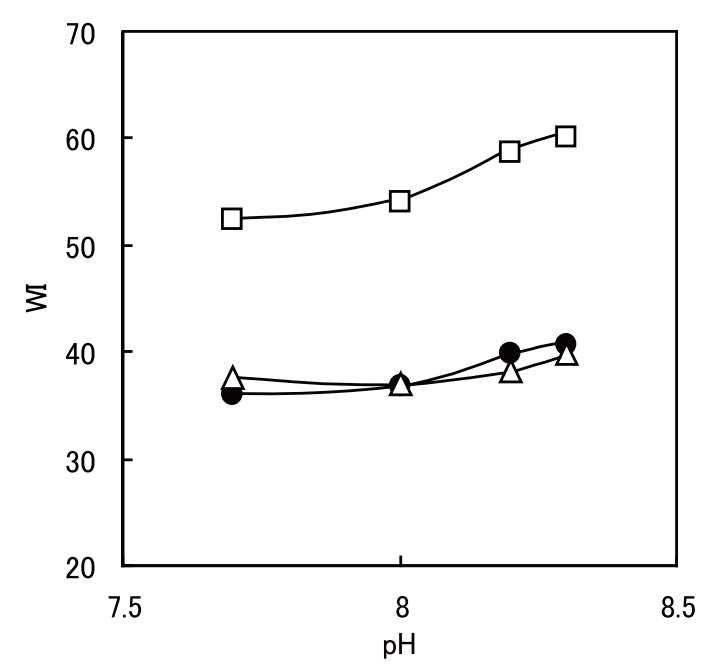

Fig. 5 Effects of alkali agents type on WI for bleached cotton fabrics $\left(\mathrm{H}_{2} \mathrm{O}_{2} \quad 0.23 \mathrm{~mol} / \mathrm{dm}^{3}, 70^{\circ} \mathrm{C}\right.$, 120min). : NaOH, $\triangle: \mathrm{NH}_{3}, \square$ : Urea

尿素と過酸化水素が含まれている Carbamide peroxide $\left(\mathrm{CH}_{4} \mathrm{~N}_{2} \mathrm{O} \cdot \mathrm{H}_{2} \mathrm{O}_{2}\right)$ は歯のホワイトニングに用いられていて, 歯に接触するとすぐ分解してヒドロキシルラジカル (HO·) , ペルヒドロキシルラジカル (HOO·), スーパーオキシドア ニオンラジカル $\left(\cdot \mathrm{O}_{2}^{-}\right)$のような酸素遊離基を生成し, 着色 物質と反応することが知られている $[16]$. その尿素によ る過酸化水素の活性化として以下のメカニズムが考えら れる $[6]$.

$$
\begin{aligned}
& \underset{\mathrm{H}_{2} \mathrm{O}_{2}+}{\mathrm{H}_{2} \mathrm{~N}} \mathrm{CO} \rightarrow{ }_{\mathrm{H}_{2} \mathrm{~N}} \mathrm{CO} \cdot \mathrm{H}_{2} \mathrm{O}_{2} \\
& \mathrm{HO} \cdot \mathrm{H}_{2} \mathrm{O}_{2} \rightarrow \mathrm{NH}_{2} \mathrm{CONH}_{2}+\mathrm{HO} \cdot \mathrm{HO} \cdot \\
& \mathrm{HO}_{2} \mathrm{O}_{2} \rightarrow \mathrm{H}_{2} \mathrm{O}+\mathrm{HO}_{2} \\
& \mathrm{H}_{2} \mathrm{O}_{2} \rightarrow \mathrm{HO} \cdot+\mathrm{H}_{2} \mathrm{O}+\mathrm{O}_{2}
\end{aligned}
$$

尿素の電離度は $1.5 \times 10^{-4}\left(25^{\circ} \mathrm{C}\right)$ で, 水に溶解したら, その中の僅かが $\mathrm{NH}_{2}{ }^{-}$となって電離する [16]. 尿素は (5) 式 のように過酸化水素と錯体 $\left(\left(\mathrm{NH}_{2}\right)_{2} \mathrm{CO} \cdot \mathrm{H}_{2} \mathrm{O}_{2}\right)$ を生成し, こ れが分解して (6) 式のようにヒドロキシルラジカルを生ず る.これがさらに(7)式のように過酸化水素を分解して, ペルヒドロキシルラジカルを生成し, さらに(8)式のよう にヒドロキシルラジカルを生ずる[17].

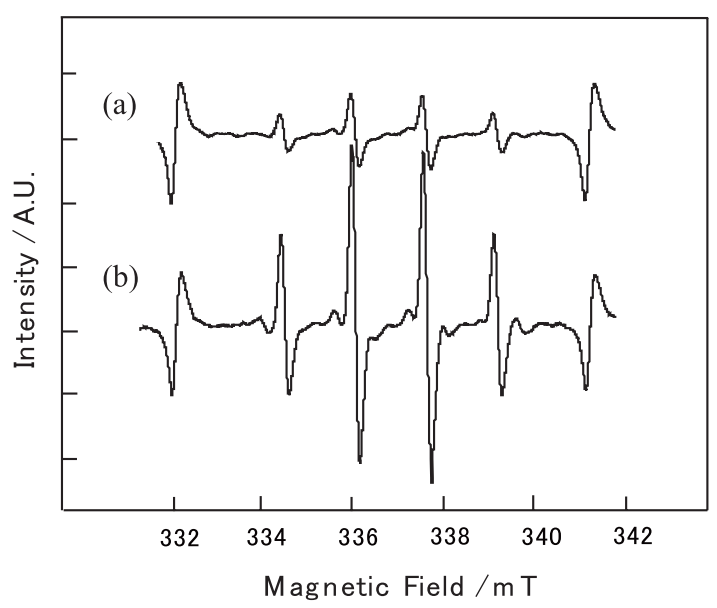

Fig. 6 ESR spectra of DMPO-OH spin adducts.

(a) $\mathrm{H}_{2} \mathrm{O}_{2} 0.23 \mathrm{~mol} / \mathrm{dm}^{3}$

(b) $\mathrm{H}_{2} \mathrm{O}_{2} 0.23 \mathrm{~mol} / \mathrm{dm}^{3}+$ Urea $0.5 \mathrm{~mol} / \mathrm{dm}^{3}$

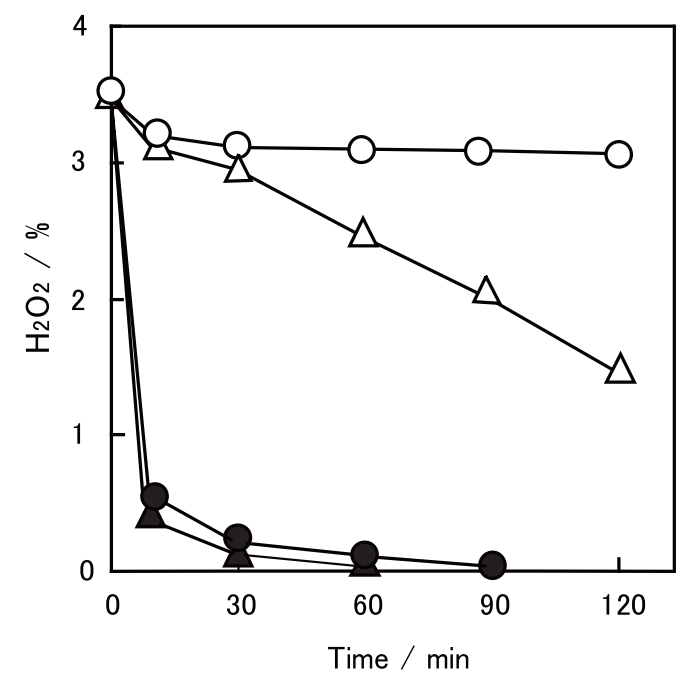

Fig. 7 Change of hydrogen peroxide concentration in bleaching baths with or without urea.

$\bigcirc$ : $\mathrm{pH} 6, \mathrm{H}_{2} \mathrm{O}_{2} \triangle$ : $\mathrm{pH} 6, \mathrm{H}_{2} \mathrm{O}_{2}+$ Urea

: pH10, $\mathrm{H}_{2} \mathrm{O}_{2} \boldsymbol{\Delta}$ : $\mathrm{pH} 10, \mathrm{H}_{2} \mathrm{O}_{2}+$ Urea

尿素を添加した過酸化水素漂白浴でラジカル生成を確 認するため, 漂白浴の ESR 測定を行った. 本研究で用い たトラップ剂 DMPO は HOO·や· $\mathrm{O}_{2}^{-} よ り \mathrm{HO}$ をトラップし やすい性質があり, 漂白浴で生成されるラジカルを特定 することはできないが, ピークの大きさで生成したラジ カルの量を比較することができる $[18] . \mathrm{pH}$ 無調製の水溶 液で, 過酸化水素単独の ESR スペクトルは, Fig. 6 の (a) のように, HO・に特有の 4 つのピークが見られ, 過酸化水 素水溶液に尿素を添加すると (b) に示したようにそのピー クがさらに大きくなった。この結果から尿素添加により ラジカルの量が増加することが分かる. 過酸化水素の解 離における尿素の影響を調べるために, 過マンガン酸カ リウム滴定で, 残留過酸化水素の濃度を測定した. pH6 と $\mathrm{pH} 10$ の漂白浴において過酸化水素濃度を測定した結果 を Fig. 7 に示す.pH6 で過酸化水素単独では 30 分で過酸 化水素の濃度がやや減少するが, それ以降はほとんど変 
化がない. しかし, 尿素を添加すると, 試料液の処理時 間の増大とともに残留過酸化水素の濃度が減少した。一 方, pH10 の漂白浴では過酸化水素単独の場合も尿素を添 加した場合も過酸化水素濃度の減少は速く, 60 分が経過 するとその濃度はゼロに近い值を示した．このように過 酸化水素水溶液における尿素の活性化作用は中性条件で 見られる。

\section{4. おわりに}

中性条件における綿布の漂白方法を確立するために, 過酸化水素による漂白に尿素を用いて検討したところ, アルカリ条件での漂白と同程度の白度が得られ, 強度低 下もなかった，尿素の過酸化水素活性化作用について調 ベたところ, 以下の知見が得られた.

高温の過酸化水素漂白浴に尿素を添加すると, $\mathrm{pH}$ はた だちに上昇し， 10 分から 60 分後にはほぼ一定となる.こ れは高温処理で, 尿素の加水分解が進み, アンモニアを 発生するためであると考えられる. 一方, 尿素の効果は $\mathrm{pH}$ の上昇によるペルヒドロキシルイオン $\left(\mathrm{HOO}^{-}\right)$の解離だけ ではなく, ヒドロキシルラジカル $(\mathrm{HO} \cdot)$, ペルヒドロキシ ルラジカル (HOO) そしてスーパーオキシドラジカルアニ オン $\left(\cdot \mathrm{O}_{2}^{-}\right)$のような活性酸素の生成によると考えられる. これは漂白浴の ESR 測定で, 尿素添加によりラジカルの 量が増加することから推定できる. 過マンガン酸カリウ ム滴定で, 時間ごとに残留過酸化水素の濃度を測定した 結果, pH6 の漂白浴では, 過酸化水素単独と異なり, 尿 素を添加すると, 処理時間とともに残留過酸化水素の濃 度は減少した. 一方, pH10の漂白浴ではいずれもほぼ同 様に過酸化水素の減少は速く, 60 分が経過するとその濃 度は 0 に近い值を示した. 以上のことから過酸化水素水 溶液における尿素の活性化作用は中性条件で現れると考 えられる。

\section{謝 辞}

本研究の漂白実験および切断強度測定の一部を担当さ れた橋本章子氏に深謝します.

\section{文 献}

1. M. Tasaka, and M. Kaimori, Kakou Gijyutu, 37 (5), 326 (2002).

2. G. Buschle-Diller, X. D. Yang, and R. Yamamoto, Text. Res. J., 71, 388 (2001).

3. C. Jin, and M. Maekawa, Sen'i Gakkaishi, 59 (8), 334 (2003).

4. Y. Maeshima, and T. Tabata, Reports of the Hamamatsu Industrial Research Institute of Shizuoka Prefecture, No.11, 56 (2001).

5. T. M. Letcher, P. Govender, and S. Lutseke, Text.Res. J., 64 (12), 761 (1994).

6. M. H. El-Rafie, A. Higazy, and A. Hebeish. Am.Dyest. Rep., 81(3), 49 (1992).

7. T. K. DAS, A. K. Mandavawalla, and S. K. Datta, Text. Dyer Printer, 19, 21 (1986).

8. N. C. Gursoy, A. El-Shafei, P. Hauser, and D. Hinks Text. Chem. Color., 4, 37 (2004).

9. A. Ouchi, Proceedings of the $10^{\text {th }}$ Asian Textile Conference at Ueda, Japan, p55-58 (2009).

10. H. Harry, Aldrichimica Acta, 26 (2), 35 (1993).

11. Patent domestic publication, 1983-167557.

12. R. S. Varma, K. P. Naicker, Org. Lett., 1, 189 (1999).

13. M. Maekawa, and S. Yang, J.Home Econ. Jpn., 59 (6), 387 (2008).

14. G. Holst, Chem. Rev., 54, 169 (1954).

15. K. Masuda, Sensyoku (Dyeing and Finishing), 16(2), 94 (1998).

16. D. Goo, T. Kwon, S. Nam, H. Kim, K. Kim, and Y. Kim, Dent Mater J, 23 (4), 522 (2004).

17. S. Mitui, "Nyouso", Kouyou, Tokyo, p.33 (1952).

18. M. Tahara, S. Yang,and M. Maekawa, Sen'i Gakkaishi, 64 (12), 366 (2008). 